\title{
Pengaruh Jarak Tanam dan Jumlah Benih Perlubang Tanam Terhadap Pertumbuhan dan Hasil Tanaman Jagung Manis (Zea Mays Saacaratha L.) Bonanza F1 Di Desa Wairkoja, Kecamatan Kewapante, Kabupaten Sikka.
}

\author{
Yovita Yasintha Bolly \\ Program Studi Agroteknologi, Fakultas Pertanian, Universitas Nusa Nipa ${ }^{1}$ \\ Jl. Kesehatan-Alok Timur, Sikka-Flores, NTT \\ Vytayovieeta@gmail.com
}

\begin{abstract}
ABSTRAK
Plant Spacing and the Number of Seeds per Planting hole is one of the factors that affect plant growth and yield. therefore. the study entitled The Effect of Planting Distance and Number of Perforated Planting Seeds on Growth and Yield of Sweet Corn (Zea mays Saacaratha L.) Bonanza F1 in Wairkoja Village, Kewapante District, Sikka Regency, has been carried out. This study uses a randomized block design (RCBD), which consists of two (2) factors, namely, spacing (J) and the number of seeds per planting hole (W) as follows $\mathrm{J} 1$ : Length $50 \mathrm{~cm} \mathrm{x}$ Width $25 \mathrm{~cm}$. These two factors are combined to obtain nine treatment combinations. The observed variables were plant height $(\mathrm{cm})$, number of leaves (strands), wet weight of trees, $\mathrm{N}, \mathrm{P}, \mathrm{K} \mathrm{pH}$, and $\mathrm{C}$-organic soil. Based on the research that has been done, it can be concluded that the treatment of spacing did not affect the growth and production of corn, the number of seeds did not affect the number of leaves and the combined treatment of the number of seeds and spacing did not affect the wet weight of the fruit.
\end{abstract}

Keywords: Plant spacing, number of seeds, Sweet Corn.

PENDAHULUAN

Jagung manis (Zea mays sacaratha L.) merupakan tanaman serealia yang paling produktif di dunia. Jagung manis merupakan salahsatukomoditas pertanianyang disukaioleh masyarakat karenarasanya yang enak yang telahbanyakdigemari baikdalamnegeri maupunluarnegeri. Adapunnilaigiziyang terkandung dalam jagung manis terdiri atas : kalori 33,00 g, protein 2,20 g, lemak 0,10 $\mathrm{g}$, hidrat arang 7,40 g, kalsium 7,00 mg, fosfor $100,00 \mathrm{mg}$, zat besi $0,50 \mathrm{mg}$, vitamin A $200 \mathrm{~S} .1$, vitamin B1 0,08 mg, vitamin C 8,00 mg, air 89,50 g. (Direktorat Gizi Depkes R.I, 1981).
Menurut data Dinas Pertanian Kabupaten Sikka (2016) produksi jagung di Kecamatan Kewapante adalah 1.578 ton dari luas tanam (897 ha), luas panen (383 ha). Kecamatan Kangae adalah 2.072 ton dari luas tanam (1.915 ha), luas panen (503 ha) . Kecamatan Hewokloang dengan luas tanam (207 ha), luas panen (682 ha) dan hasil 2.811 ton.

Menurut Mayadewi (2007), berbagai pola pengaturan jarak tanam telah dilakukan guna mendapatkan produksi yang optimal. Penggunaan jarak tanam pada tanaman jagung dipandang perlu, karena untuk mendapatkan pertumbuhan tanaman yang seragam, distribusi unsur hara 
yang merata, efektivitas penggunaan lahan, memudahkan pemeliharaan, menekan pada perkembangan hama dan penyakit juga untuk mengetahui berapa banyak benih yang diperlukan pada saat penanaman. Penggunaan jarak tanam yang terlalu rapat akan menyebabkan daun tanaman saling menutupi, sehingga pertumbuhan tanaman jagung manis akan tinggi dan memanjang karena persaingan untukmendapatkan cahaya sehingga menghambat proses fotosentesis dan produksi tanaman tidak optimal.

Menurut Janick (2009),pengaturan jumlah benih per lubang tanam merupakan suatu cara yang sederhana untuk mengatur cahaya yang diterima oleh tanaman. Umumnya hasil yang meningkat per satuan luas akan tercapai dengan kepadatan yang tinggi, karena penggunaan cahaya secara maksimal pada awal pertumbuhan, tetapi akhirnya sifat tiap-tiap induk menurun karena persaingan cahaya dan faktor-faktor tumbuh lain, dalam hal ini respon ditunjukan dengan menurunnya ukuran tanaman atau bagian lainnya.

\section{Menurut Aribawa (2007),} pengaturan jarak tanam berkaitan erat dengan produksi yang akan dicapai. Jarak tanam yang tidak teratur akan memungkinkan terjadi kompetisi terhadap cahaya matahari, unsur hara, air dan antara individu tanaman, sehingga pengaturan jarak tanam yang sesuai dapat mengurangi terjadinya kompetisi terhadap faktor-faktor tumbuh tanaman. Pada prinsipnya pengaturan jarak tanaman untuk memberikan tanaman tumbuh lebih baik tanpa mengalami banyak persaingan. Mengatur jarak tanam bertujuan untuk meminimalkan terjadinya kompetisi intraspesies maupun inter-species dan merupakan suatu tindakan manipulasi agar kanopi dan akar tanaman dapat memanfaatkan lingkungan secara optimal.

Dari hasil penelitian simamora (2007), perlakuan jarak tanam berpengaruh nyata terhadap hasil jagung perplot. Jarak tanam $60 \mathrm{~cm} \quad$ x $\quad 25 \mathrm{~cm} \quad(351286 \mathrm{~g})$ memberikan hasil lebih besar dibandingkan $75 \mathrm{~cm}$ x $25 \mathrm{~cm}(2853,33 \mathrm{~g})$ dan $90 \mathrm{~cm} \mathrm{x} 25 \mathrm{~cm}(2474,67 \mathrm{~g})$, jarak tanam yang semakin renggang akan menyebabkan penurunan hasil sebesar $15 \%$ pada jarak tanam $75 \mathrm{~cm} \times 25 \mathrm{~cm}$ dan $29 \%$ pada jarak tanam $90 \mathrm{~cm} \times 25 \mathrm{~cm}$ besarnya produksi dipengaruh oleh jumlah populasi tanaman. Untuk meningkatkan hasil biji tanaman jagung salah satunya adalah dapat dilakukan dengan penambahan tingkat kerapatan tanaman per satuan luas. Jarak tanam yang lebih renggang menghasilkan hasil yang lebih besar per tanaman, namun pada jarak tanam yang lebih sempit sampai batas tertentu akan menghasilkan hasil yang lebih besar. Perlakuan $60 \mathrm{~cm} \times 25 \mathrm{~cm}$ belum menimbulkan persaingan yang nyata antara tanaman jagung sehingga hasilnya lebih besar dibandingkan perlakuan jarak tanam $75 \mathrm{~cm}$ x $25 \mathrm{~cm}$ dan $90 \mathrm{~cm} \times 25 \mathrm{~cm}$.

Hasil penelitian Arwani, (2013) menunjukkan, perlakuan jumlah benih per lubang berpengaruh meningkatkan pertumbuhan dan hasil tanaman jagung manis yaitu, tinggi tanaman saat berumur 7 minggu setelah tanam, berat segar per tanaman, berat segar per lubang, berat kering per tanaman, berat kering per lubang, berat tongkol konsumsi per tanaman, berat tongkol konsumsi per lubang, dan jumlah tongkol per lubang. Perlakuan 1 benih per tanaman memperoleh hasil tertinggi pada tinggi tanaman saat berumur 7 minggu setelah tanam, berat segar per tanaman, berat 
keringper tanaman, dan berat tongkol konsumsi per tanaman, dan perlakuan 3 benih per lubang memperoleh hasil tertinggi pada berat segar per lubang yaitu $2574,55 \mathrm{~g}$, berat kering per lubang yaitu $600,81 \mathrm{~g}$, berat tongkol konsumsi per lubang yaitu $668 \mathrm{~g}$, dan jumlah tongkol per lubang yaitu 3,55 tongkol.

\section{METODE PENELITIAN}

Tempat dan Waktu Penelitian

Penelitian ini dilaksanakan pada bulan Mei 2017 sampai bulan Agustus 2017 di Desa Wairkoja, Kecamatan Kewapante, Kabupaten Sikka.

\section{Alat dan Bahan}

1. Alat-alat yang telah digunakan dalam penelitian ini adalah, cangkul, parang, timbangan, meter, papan perlakuan, label, gembor, patok, tali rafia, kayu tugal, kamera, penggaris dan alat tulis menulis.

2. Bahan yang telah digunakan dalam penelitian ini adalah, benih jagung manis jenis Bonanza F1.

\section{Rancangan Penelitian}

Rancangan percobaan yang digunakan pada penelitian ini adalah rancangan acak kelompok (RAK), yang terdiri dari dua (2) faktor yaitu, jarak tanam (J) dan faktor jumlah benih per lubang tanam (W) sebagai berikut :

Faktor pertama (I) : jarak tanam jagung (J) :

J1 : Panjang $50 \mathrm{~cm}$ x Lebar $25 \mathrm{~cm}$

J2 : Panjang $60 \mathrm{~cm} \times$ Lebar $25 \mathrm{~cm}$

J3 : Panjang $70 \mathrm{~cm} \times$ Lebar $25 \mathrm{~cm}$

Faktor kedua (II) : jumlah benih per lubang tanam $(\mathrm{W})$ :

W1 : 1 benih jagung per lubang tanam

W2 : 2 benih jagung per lubang tanam

W3 : 3 benih jagung per lubang tanam

Kedua faktor dikombinasikan sehingga diperoleh 9 kombinasi perlakuan seperti pada tabel 1.

Tabel 1. Unit Perlakuan Jarak Tanam dan Jumlah Benih Per Lubang Tanam.

\begin{tabular}{|c|c|c|c|c|c|c|c|c|}
\hline \multirow[t]{2}{*}{ Jarak tanam } & \multirow{2}{*}{$\begin{array}{l}\text { Jumlah benih } \\
\text { Per lubang }\end{array}$} & \multirow{2}{*}{$\begin{array}{l}\text { Perlakuan } \\
\text { Kombinasi }\end{array}$} & \multicolumn{6}{|c|}{ Ulangan } \\
\hline & & & 1 & & 2 & & 3 & \\
\hline \multirow{3}{*}{ J1 } & W1 & J1W1 & J1W1 & 1 & J1W1 & 2 & J1W1 & 3 \\
\hline & W2 & J1W2 & $\mathrm{J} 1 \mathrm{~W} 2$ & 1 & J1W2 & 2 & J1W2 & 3 \\
\hline & W3 & J1W3 & $\mathrm{J} 1 \mathrm{~W} 3$ & 1 & J1W3 & 2 & J1W3 & 3 \\
\hline \multirow{3}{*}{$\mathrm{J} 2$} & W1 & $\mathrm{J} 2 \mathrm{~W} 1$ & $\mathrm{~J} 2 \mathrm{~W} 1$ & 1 & $\mathrm{~J} 2 \mathrm{~W} 1$ & 2 & $\mathrm{~J} 2 \mathrm{~W} 1$ & 3 \\
\hline & W2 & $\mathrm{J} 2 \mathrm{~W} 2$ & $\mathrm{~J} 2 \mathrm{~W} 2$ & 1 & $\mathrm{~J} 2 \mathrm{~W} 2$ & 2 & $\mathrm{~J} 2 \mathrm{~W} 2$ & 3 \\
\hline & W3 & $\mathrm{J} 2 \mathrm{~W} 3$ & $\mathrm{~J} 2 \mathrm{~W} 3$ & 1 & $\mathrm{~J} 2 \mathrm{~W} 3$ & 2 & $\mathrm{~J} 2 \mathrm{~W} 3$ & 3 \\
\hline \multirow{3}{*}{$\mathrm{J} 3$} & W1 & J3W1 & J3W1 & 1 & J3W1 & 2 & J3W1 & 3 \\
\hline & W2 & J3W2 & J3W2 & 1 & J3W2 & 2 & $\mathrm{~J} 3 \mathrm{~W} 2$ & 3 \\
\hline & W3 & J3W3 & J3W3 & 1 & J3W3 & 2 & J3W3 & 3 \\
\hline
\end{tabular}

Masing-masing kombinasi perlakuan diulang 3 kali, sehingga diperoleh 27 bedengan (unit perlakuan).

\section{Pelaksanaan Penelitian}

Pelaksanaan penelitian meliputi Persiapan lahan, Pengolahan tanah, Pembuatan bedengan, Penanaman, Pemeliharaan tanaman jagung manis, Penyiraman,
Penyiangan, Pembumbunan, Pengendalian hama dan penyakit dan Pemanenan

\section{Variabel yang diamati}


1. Variabel utama: Tinggi tanaman $(\mathrm{cm})$, Jumlah daun (helai), Bobot basah perpohon. Variabel Pendukung meliputi Analisis kandungan N,P,K $\mathrm{pH}$, C-organik tanah awal sebelum melakukan penelitian.

\section{Metode pengumpulan data}

1) Metode survei lapangan Data yang diperoleh secara langsung pada saat penelitian yaitu dengan membuat perlakuan setiap unit percobaan yang diteliti, setiap kejadian dicatat dengan baik.

2) Menelaah dari berbagai literatur atau refrensi sesuai dengan topik penelitian.

\section{Model Analisis Data}

Model analisis data rancangan acak kelompok (RAK) 2 faktorial menurut Mattjik dan Sumertajaya (2006) adalah:

\section{$Y \mathbf{i j k}=\mu+p k+\alpha i+\beta j+(\alpha \beta) i j+\varepsilon i j k$}

Yijk : Nilai pengamatan

$\mu \quad$ : Rataan umum

pk : Pengaruh kelompok pada taraf ke-k

ai : Pengaruh faktor A pada taraf ke-i

$\beta \mathrm{j} \quad$ : Pengaruh faktor $\mathrm{B}$ pada taraf ke-j

$(\alpha \beta) \quad$ :Pengaruh kombinasi dari faktor A pada taraf ke-I dan faktor B pada taraf ke- j

eijk : Pengaruh galat dari faktor A pada taraf ke-i dan faktor
B pada taraf ke-j pada ulangan ke-k

Data yang diperoleh dianalisis dengan menggunakan rancangan acak kelompok (RAK) dan bila hasil uji ANOVA (Analisis of Variance)berbeda tidak nyata (F hitung $<\mathrm{F}$ tabel $5 \%$ ) tidak dilakukan uji lanjutan, sedangkan bila hasil sidik ragam berbeda nyata ( $\mathrm{F}$ hitung $>\mathrm{F}$ tabel $5 \%)$ atau berbeda sangat nyata (F hitung > F tabel $1 \%)$, maka untuk membandingkan dua rata-rata perlakuan dilakukan uji lanjutan dengan uji Beda Nyata Terkecil (BNT) taraf $5 \%$ dengan rumus sebagai berikut :

$$
B N T 5 \%=t \alpha \times \sqrt{\frac{2 . \text { KTGalat }}{r}}
$$

Keterangan :

$\mathrm{t}-\alpha=$ nilai $\mathrm{t}$-tabel $($ pada $\alpha=5$

$\%$, dan derajat bebas galat)

KT galat = kuadrat tengah galat

$\mathrm{R}=$ jumlah blok

\section{HASIL DAN PEMBAHASAN \\ Hasil Analisis Tanah Awal}

Sebelum dilakukan penelitian pengaruh jarak tanam dan jumlah benih perlubang tanam, terlebih dahulu tanah awal dianalisis di Laboratorium untuk mengetahui kandungan Kimia Tanah. Hasil analisis tanah awal yang dilksanakan di Laboratorium Kimia Tanah Universitas Nusa Cendana Kupang terlihat pada tabel 2 
Tabel 2. Hasil Analisis Tanah Awal Di Kloangbolat Desa WaerkojaKecamatan Kewapante Kabupaten Sikka.

\begin{tabular}{llccc}
\hline No & Parameter & Satuan & Hasil Analisis & Kriteria \\
\hline 1 & C-organik & $\%$ & 3,1 & Tinggi \\
2 & N Total & $\%$ & 0,44 & Sedang \\
3 & $\mathrm{P}_{2} \mathrm{O}_{5}$ & $\mathrm{ppm}$ & 30,55 & Tinggi \\
4 & $\mathrm{~K}$ & $\mathrm{me} / 100 \mathrm{~g}$ & 1,15 & Tinggi \\
5 & $\mathrm{pH}$ & - & 6,81 & Netral \\
\hline
\end{tabular}

Sumber: Analisis Tanah Laboratorium Kimia Tanah Universitas Cendana Kupang 2017.

Berdasarkan data analisis pada Tabel 2 menunjukkan bahwa kondisi tanah yang digunakan dalam penelitian ini memiliki kandungan $\mathrm{C}$ - organik tergolong tinggi yaitu 3,1\% dan kandungan $\mathrm{N}$ total $(0,44 \%)$ tergolong sedang, dan kandungan $\mathrm{P}_{2} \mathrm{O}_{5}(30,55)$ ppm tergolong tinggi, serta kandungan $\mathrm{K}(1,15) \mathrm{me} / 100 \mathrm{~g}$ tergolong tinggi, dengan $\mathrm{pH}$ tanah yaitu 6,81 dengan kategori netral. (Hardjowigeno, 2005)

Dari hasil analisis tanah awal terlihat jelas bahwa kandungan C-organik didalam tanah tergolong tinggi, sementara kandungan C-organik memiliki peran penting dalam proses pertumbuhan tanaman. Fungsi C-organik antara lain:Meningkatkan kesuburan tanah dan menyediakan mikro hara dan faktor-faktor pertumbuhan lainnya yang biasanya tidak disediakan oleh pupuk kimia (anorganik) dan tanah dengan bahan organik rendah, mempunyai daya simpanunsur hara yang rendah pula. (Darliana, 2009)

Selanjutnya kandungan unsur hara $\mathrm{N}$ (Nitrogen)tergolong sedang dimana Nitrogen merupakan unsur hara utama bagi pertumbuhan tanaman, yang pada umumnya sangat diperlukan untuk pertumbuhan vegetatif tanaman seperti daun, batang dan akar. Fungsi Nitrogen bagi tanaman adalah untuk meningkatkan pertumbuhan tanaman, dandapat menunjang pertumbuhan daun sehingga membentuk klorofil.Apabila tanaman kekurangan $\mathrm{N}$ maka pertumbuhan menjadi terhambat, layu dan kerdil (Winarso 2005).

Kandungan Fosfor $\left(\mathrm{P}_{2} \mathrm{O}_{5}\right)$ dari tabel analisis tergolong tinggi karena sumber utama fosfor adalah hasil dari pelapukan batuan atau bahan induk serta hasil mineralisasi $\mathrm{P}$ organik hasil dekomposisi sisa-sisa tanaman dan hewan yang terlarut didalam tanah. Jika tanah mengandung $1 \%$ bahan organik berarti terdapat $200 \mathrm{~kg}$ kandungan $\mathrm{P}$ organik/ha.Fungsi utama dari unsur $\mathrm{P}$ adalah mempercepat pertumbuhan akardan memperkuat pertumbuhan tanaman muda menjadi dewasa, mempercepat pembungaan dan pemasakan biji serta meningkatkan produksi. (Handoko, 2000).

Kalium tergolong tinggi karena unsur $\mathrm{K}$ merupakan unsur hara makro kedua setelah $\mathrm{N}$ yang paling banyak diserap oleh tanaman. Tanaman menyerap ion $\mathrm{K}+$ dari hasil pelapukan dan dekomposisi bahan organik yang terlarut dalam tanah. Secara fisiologis unsur K berfungsi sebagai metabolisme nitrogen dan sintesis protein, pengaturan buka tutup stomata dan pengaturan berkaitan dengan penggunaan air. Unsur kalium diserap tanaman dalam bentuk ion $\mathrm{K}+$ memiliki peranan yang penting dalam tanaman diantaranya sebagai elemen penting yang bersifat higroskopis (mudah menyerap dan 
menahan air). Unsur $\mathrm{K}$ biasanya terdapat pada stomata daun. Dengan sifatnya pada proses transpirasi, fotosintesis, absorsi, maupun transportasi unsur hara dalam tanaman menjadi optimal. (Anonimous, 2002)

Derajat keasaman $(\mathrm{pH})$ sangat berpengaruh terhadap ketersediaan hara didalam tanah, aktifitas kehidupan jasad renik tanah dan reaksi pupuk yang diberikan kedalam tanah. Penambahan pupuk kedalam tanah secara langsung akan mempengaruhi keasamannya, karena dapat menimbulkan reaksi asam, ataupun basah, yang secara langsung atau tidak langsung dapat mempengaruhi ketersediaan unsur hara makro dan unsur hara mikro. Ketersedian unsur hara mikro lebih tinggi pada $\mathrm{pH}$ rendah. Semakin tinggi $\mathrm{pH}$ tanah ketersediaan hara mikro semakin sedikit (Haryanto $d k k, 2006$ ).

\section{Hasil pengamatan Tanaman Jagung Manis \\ Data hasil pengamatan tinggi tanaman jagung manis di lapangan tahap pertama terlihat pada tabel 4.2.}

Tabel 3. Tinggi Tanaman (cm) 20 (hst)

\begin{tabular}{ccccccc}
\hline \multirow{2}{*}{ Jarak } & Benih/Lubang & \multicolumn{3}{c}{ Kelompok/Ulangan } & Jumlah/Total & Rerata \\
\cline { 3 - 4 } & & I & II & III & & \\
\cline { 3 - 4 } J1 & W1 & 28,5 & 26,8 & 30,3 & 85,67 & 28,56 \\
& W2 & 33,4 & 35,4 & 35,4 & 104,23 & 34,74 \\
& W3 & 35,28 & 31,56 & 28,72 & 95,56 & 31,85 \\
& w1 & 23,83 & 26,67 & 27,83 & 78,33 & 26,11 \\
J2 & w2 & 29,25 & 32,5 & 32,92 & 94,67 & 31,56 \\
& & & & & & \\
& w3 & 17,11 & 33,44 & 36,17 & 86,72 & 28,91 \\
& W1 & 29,33 & 32 & 31,17 & 92,50 & 30,83 \\
J3 & W2 & 33,67 & 35,25 & 30,25 & 99,17 & 33,06 \\
& W3 & 31,06 & 33,56 & 27,72 & 92,33 & 30,78 \\
\hline
\end{tabular}

Sumber: data perimer diolah,( 2017)

Pada pengamatan pertama (tabel 2) rata-rata tinggi tanaman umur $20 \mathrm{hst}$ menunjukan tidak berpengaruh nyata dimana dalam uji ANOVA F hitung lebih kecil dibandingkan $\mathrm{F}$ tabel. Hasil pengamatan menunjukan rata-rata tinggi tanaman pada jarak tanam $50 \mathrm{~cm}$ dengan jumlah 2 benih/lubang tanam (J1W2) tergolong tinggi yaitu, $(34,74 \mathrm{~cm})$. Sedangkan terendah pada jarak $50 \mathrm{~cm}$ dengan jumlah 1 benih/lubang tanam (J1W1) yaitu, (28,56 cm).
Hal ini disebabkan populasi tanaman yang relatif rendah memungusahakan tanaman jagung manis tidak saling menaungi sehingga dapat memenuhi kebutuhan radiasi matahari dan unsur hara. Sesuai dengan pernyataan Simamora, (2006) jarak tanam mempengaruhi populasi tanaman dan koefisien penggunaan cahaya, menpengaruhi kompetisi antara tanaman dalam menggunakan air dan zat hara, sehingga akan mempengaruhi hasil. 
Menurut Bilman, (2011) hal ini terjadi karena, semakin besar dan semakin rapat tanaman jagung akan memacu tanaman untuk menyerap unsur hara, air, cahaya, untuk pertumbuhan tinggi tanaman. Cukupnya kebutuhan tanaman terhadap unsur-unsur pertumbuhan akan merangsang pertambahan tinggi tanaman dan pembentukan daun-daun baru.
Berkelaar, (2011) berpendapat bahwa pemakaian benih per lubang tanam berpengaruh terhadap pertumbuhan karena secara langsung berhadapan dengan kompetisi antar tanaman dalam satu rumpun. Jumlah bibit per lubang tanam yang lebih sedikit akan memberikan ruang pada tanaman untuk menyebar dan memperdalam perakaran.

Tabel 4. Data tinggi Tanaman (cm) $40 \mathrm{hst}$

\begin{tabular}{|c|c|c|c|c|c|c|}
\hline Jarak & Benih/Lubang & \multicolumn{3}{|c|}{ Kelompok/Ulangan } & \multirow[t]{2}{*}{ Jumlah/Total } & \multirow[t]{2}{*}{ Rerata } \\
\hline \multirow{4}{*}{$\mathrm{J} 1$} & & I & II & III & & \\
\hline & W1 & 68,67 & 94,8 & 87,8 & 251,33 & 83,78 \\
\hline & W2 & 107,4 & 112,2 & 112,0 & 331,58 & 110,53 \\
\hline & W3 & 111,28 & 112,72 & 114,11 & 338,11 & 112,70 \\
\hline \multirow{3}{*}{$\mathrm{J} 2$} & w1 & 102,83 & 115,50 & 108,33 & 326,67 & 108,89 \\
\hline & w2 & 111,08 & 112,75 & 115,17 & 339,00 & 113,00 \\
\hline & w3 & 107,28 & 116,67 & 111,17 & 335,11 & 111,70 \\
\hline \multirow{3}{*}{$\mathrm{J} 3$} & W1 & 106,17 & 108,33 & 108,33 & 322,83 & 107,61 \\
\hline & W2 & 117,42 & 120,67 & 95,92 & 334,00 & 111,33 \\
\hline & W3 & 100,39 & 105,78 & 98,17 & 304,33 & 101,44 \\
\hline
\end{tabular}

Sumber: data perimer diolah, (2017)

Pada pengamatan kedua (tabel 3) rata-rata tinggi tanaman umur 40 hst menunjukan tidak berpengaruh nyata dimana dalam uji ANOVA $F$ hitung lebih kecil dibandingkan $\mathrm{F}$ tabel. Walaupun hasil analisis tidak berbeda nyata akan tetapi, tinggi tanaman jagung manis pada umur 40 hst terbanyak terdapat pada jarak tanam $60 \mathrm{~cm}$ dengan jumlah 2 benih/lubang tanam (J2W2) dengan rerata tertinggi $(113,00 \mathrm{~cm})$. Sedangkan rata-rata tinggi tanaman jagung manis terendah terdapat pada jarak tanam $50 \mathrm{~cm}$ dengan jumlah1 benih/lubang tanam (J1W1) yaitu, $(83,78 \mathrm{~cm})$. Hal ini menunjukan bahwa, semakin besar tanaman semakin besar pula kebutuhan akan cahaya dan unsur hara. Menurut Rifin, (2011) cahaya matahari adalah faktor penting dalam proses fotosintesis dan penentu laju pertumbuhan tinggi tanaman sehingga intensitas lama penyinaran dan kualitasnya sangat berpengaruh terhadap proses fotosintesis tersebut.

Sedangkan menurut Ermanita, (2004) faktor yang dapat mempengaruhi pertumbuhan dan produksi jagung adalah dengan pengaturan jarak tanam dan pengaturan jumlah benih per lubang tanam. Pengaturan jarak tanam untuk tanaman sangat diperlukan agar setiap individu tanaman dapat memanfaatkan semua faktor lingkungan tumbuhnya dengan optimal, sehingga tanamantumbuh 
dengan subur dan seragam yang akhirnya pertumbuhan dan produksi dapat dicapai secara optimal.

Didukung dengan pandangan Harjadi, (2012) bahwa sinar matahari, air dan unsur hara itu sendiri dapat menghemat penggunaan sarana produksi. Populasi tanaman yang tinggi mendorong tanaman untuk menggunakan sejumlah air, unsur hara dan cahaya semakin optimal. Penggunaan sarana tumbuh yang mendorong terpacunya tinggi tanaman yang lebih baik, sehingga meningkatkan hasil tanaman. Setelah mencapai populasi optimal, kenaikan populasi selanjutnya akan menurunkan hasil. Penurunan hasil tersebut diakibatkan oleh meningkatnya persaingan dalam mendapatkan cahaya, unsur hara, air dan ruang tumbuh.

Hasil penelitian Arwani, (2013) menunjukkan perlakuan jumlah benih per lubang berpengaruh meningkatan pertumbuhan dan hasil tanaman jagung manis yaitu tinggi tanaman saat berumur 7 minggu setelah tanam (mst), berat segar brangkasan per tanaman, berat segar brangkasan per lubang, berat kering brangkasan per tanaman, berat kering brangkasan per lubang, berat tongkol konsumsi per tanaman, berat tongkol konsumsi per lubang, dan jumlah tongkol per lubang. Sedangkan terhadap jumlah tongkol per tanaman, perlakuan jumlah benih tidak berpengaruh.

Menurut (Aribawa, 2007) bahwa pengaturan jarak tanam erat kaitannya dengan pertumbuhan dan produksi yang akan dicapai. Jarak tanam yang tidak teratur akan memungkinkan terjadi kompetisi terhadap cahaya matahari, unsur hara, air dan diantara individu tanaman, sehingga pengaturan jarak tanam yang sesuai dapat mengurangi terjadinya kompetisi terhadap faktor-faktor tumbuh tanaman dan pada prinsipnya pengaturan jarak tanaman untuk memberikan tanaman tumbuh lebih baik tanpa mengalami banyak persaingan. Mengatur jarak tanam bertujuan untuk meminimalkan terjadinya kompetisi intra-spesies maupun interspecies dan merupakan suatu tindakan manipulasi agar kanopi dan akar tanaman dapat memanfaatkan lingkungan secara optimal.

Tabel 5 Data Jumlah Daun (helai) 20 hst

\begin{tabular}{|c|c|c|c|c|c|c|}
\hline \multirow[t]{2}{*}{ Jarak } & \multirow[t]{2}{*}{ Benih/Lubang } & \multicolumn{3}{|c|}{ Kelompok/Ulangan } & \multirow[t]{2}{*}{ Jumlah/Total } & \multirow[t]{2}{*}{ Rerata } \\
\hline & & I & II & III & & \\
\hline \multirow{3}{*}{$\mathrm{J} 1$} & W1 & 4,67 & 4,5 & 4,2 & 13,33 & 4,44 \\
\hline & W2 & 5,3 & 5,3 & 4,5 & 15,08 & 5,03 \\
\hline & W3 & 5,22 & 5,11 & 5,06 & 15,39 & 5,13 \\
\hline \multirow{3}{*}{$\mathrm{J} 2$} & w1 & 4,83 & 5,17 & 4,33 & 14,33 & 4,78 \\
\hline & w2 & 4,33 & 5 & 700 & 16,33 & 5,44 \\
\hline & w3 & 4,89 & 4,83 & 4,78 & 14,50 & 4,83 \\
\hline \multirow{3}{*}{$\mathrm{J} 3$} & W1 & 4,33 & 4,50 & 4,50 & 13,33 & 4,44 \\
\hline & W2 & 5,08 & 4,58 & 4,58 & 14,25 & 4,75 \\
\hline & W3 & 4,61 & 4,56 & 4,56 & 13,72 & 4,57 \\
\hline
\end{tabular}

Sumber: data perimer diolah, (2017) 
Pada pengamatan pertama (tabel 4) ratarata tinggi jumlah daun umur 20 hst menunjukan tidak berpengaruh nyata dimana dalam uji ANOVA $F$ hitung lebih kecil dibandingkan $\mathrm{F}$ tabel. Hasil pengamatan menunjukan rata-rata tinggi jumlah daun pada jarak tanam $50 \mathrm{~cm}$ dengan jumlah 1 benih/lubang tanam (J1W1) tergolong rendah yaitu, (4,44 helai) sedangkan tertinggi berada pada jarak $60 \mathrm{~cm}$ dengan jumlah 2 benih/lubang tanam (J2W2) yaitu, (5,44 helai). Hal ini diduga perlakuan jarak tanam $60 \mathrm{~cm}$ dengan 2 benih berkontribusi terhadap peningkatan jumlah daun. Sesuai yang dikemukakan oleh Setiawan, (2003) meningkatnya populasi tanaman jagung akan mengakibatkan kesempatan tanaman secara individu untuk memperoleh sinar matahari, unsur hara dan air menjadi terbatas sehingga mengurangi aktivitas fotosintesis tanaman tersebut.
Erat kaitan yang dikemukakan oleh Reta-Sanchez dkk, (2002) bahwa, jumlah sebaran dan sudut daun pada suatu tajuk tanaman menentukan serapan dan sebaran cahaya matahari, sehingga mempengaruhi fotosintesis dan hasil tanaman. Faktor lainnya yang mempengaruhi kepadatan populasi yaitu jarak antar barisan dan bentuk tajuk yang akan mempengaruhi sebaran daun.

Arwadi, (2013) kerapatan tanaman berpengaruh terhadap pembentukan jumlah daun. Hal ini berhubungan dengan proses fotosintesis tanaman, yaitu semakin rapat jarak antar tanaman maka akan semakin rendah laju fotosintesis yang terjadi, karena terjadi persaingan dalam memperoleh air, unsur hara, dan cahaya matahari yang sangat dibutuhkan bagi berlangsungnya proses fotosintesis.

Tabel 6. Data Jumlah Daun (helai) 40 hst

\begin{tabular}{|c|c|c|c|c|c|c|}
\hline Jarak & Benih/Lubang & & ook/Ula & & Jumlah/Total & Rerata \\
\hline \multirow{4}{*}{$\mathrm{J} 1$} & & I & II & III & & \\
\hline & W1 & 8,00 & 10,0 & 8,7 & 26,67 & 8,89 \\
\hline & W2 & 9,6 & 9,7 & 9,3 & 28,80 & 9,50 \\
\hline & W3 & 7,67 & 8,39 & 8,56 & 24,61 & 8,20 \\
\hline \multirow{3}{*}{$\mathrm{J} 2$} & w1 & 10,33 & 11,33 & 10,33 & 32,00 & 10,67 \\
\hline & w2 & 9,67 & 9,75 & 8,83 & 28,25 & 9,42 \\
\hline & w3 & 8,94 & 9,56 & 9,11 & 27,61 & 9,20 \\
\hline \multirow{3}{*}{$\mathrm{J} 3$} & W1 & 10,83 & 11,00 & 10,50 & 32,33 & 10,78 \\
\hline & W2 & 10,58 & 10,00 & 8,83 & 29,42 & 9,81 \\
\hline & W3 & 8,44 & 8,89 & 8,22 & 25,56 & 8,52 \\
\hline
\end{tabular}

Sumber: data perimer diolah, (2017)

Pada pengamatan kedua (tabel 5) rata-rata tinggi jumlah daun umur 40 hst menunjukan tidak berpengaruh nyata dimana dalam uji ANOVA $F$ hitung lebih 
kecil dibandingkan $\mathrm{F}$ tabel. Hasil pengamatan menunjukan bahwa, rata-rata tinggi jumlah daun pada jarak tanam 70 $\mathrm{cm}$ dengan jumlah 1 benih/lubang tanam (J3W1) tergolong tinggi yaitu, (10,78 helai). Sedangkan terendah pada jarak tanam $50 \mathrm{~cm}$ dengan jumlah 3 benih/lubang tanam (J1W3) yaitu, (8,20 helai). Hal ini disebabkan jarak tanam 70 $\mathrm{cm}$ dengan jumlah 1 benih dapat menyerap cahaya dan unsur hara secara optimal sehingga dapat pula memberi pengaruh terhadap tinggi jumlah daun dibandingkan jarak tanam $50 \mathrm{~cm}$ dengan jumlah 3 benih.

Menurut Stewart, (2003) sebaran tajuk dalam daun mengakibatkan cahaya yang diterima setiap helai daun tidak sama. Semakin dekat dengan permukaan tanah semakin sedikit cahaya yang diterima oleh daun, ini adalah akibat pemadaman cahaya yang dilakukan oleh lapisan daun yang lebih atas. Jika lapisan tajuk bagian bawah menerima cahaya di bawah titik kompensasi cahayanya, maka daun ini akan bersifat parasit terhadap tanaman itu sendiri, karena karbohidrat yang dihasilkan lebih kecil dari yang digunakan untuk pemeliharaan daun tersebut. Persaingan antar tanaman menyebabkan masing- masing tanaman harus tumbuh lebih tinggi agar memperoleh cahaya lebih banyak dan pemanjangan batang pada tanaman sering menguntungkan dalam persaingan memperebutkan cahaya matahari.

$$
\text { Menurut Bilman, (2011) }
$$

pembentukan daun baru akan berakibat meningkatkan jumlah daun tanaman sehingga luas pula daun total yang dihasilkan per tanaman walaupun luas daun per individu kecil. Luas daun bertambah berarti meningkat pula penyerapan cahaya oleh daun. Daun sebagai tempat biologisnya fotosintesis sangat menentukan penyerapan dan perubahan energi cahaya dalam pembentukan biji dan hasil panen.

Selanjutnya pandangan Kurniawan, (2005) fotosintesis adalah fungsi utama dari daun tumbuhan. Proses fotosintesis ialah proses dimana tumbuhan menyerap karbondioksida dan air untuk menghasilkan gula dan oksigen yang diperlukan sebagai makanannya. Tumbuhan menyerap cahaya karena mempunyai pigmen yang disebut klorofil. Klorofil terdapat dalam kloroplast. Klorofil menyerap cahaya yang akan digunakan dalam fotosintesis.

Tabel 8. Bobot basah (gram) 80 (hst)

\begin{tabular}{|c|c|c|c|c|c|c|}
\hline Jarak & Benih/Lubang & & hpok/Ula & & Jumlah/Total & Rerata \\
\hline \multirow{4}{*}{$\mathrm{J} 1$} & & I & II & III & & \\
\hline & W1 & 166,67 & 333,3 & 333,3 & 833,33 & 277,78 \\
\hline & W2 & 533,3 & 466,7 & 516,7 & 1516,67 & 505,56 \\
\hline & W3 & 355,56 & 344,44 & 333,33 & 1033,33 & 344,44 \\
\hline \multirow{3}{*}{$\mathrm{J} 2$} & w1 & 500,00 & 483,33 & 466,67 & 1450,00 & 483,33 \\
\hline & w2 & 433,33 & 500 & 500 & 1433,33 & 477,78 \\
\hline & w3 & 322,22 & 277,78 & 255,56 & 855,56 & 285,19 \\
\hline \multirow{3}{*}{$\mathrm{J} 3$} & W1 & 400,00 & 400,00 & 366,67 & 1166,67 & 388,89 \\
\hline & W2 & 333,33 & 450,00 & 366,67 & 1150,00 & 383,33 \\
\hline & W3 & 188,89 & 244,44 & 222,22 & 655,56 & 218,52 \\
\hline
\end{tabular}

Sumber: data perimer diolah, 2017 
Pada pengamatan kedua (tabel 6) rata-rata tinggi bobot basah umur 80 hst menunjukan tidak berpengaruh nyata dimana dalam uji ANOVA $F$ hitung lebih kecil dibandingkan $\mathrm{F}$ tabel. Hasil pengamatan menunjukan bahwa, rata-rata tinggi bobot basah buah jadi, pada jarak tanam $50 \mathrm{~cm}$ dengan jumlah 2 benih/lubang tanam (J1W2) tergolong tinggi yaitu, (505,56 gram). Sedangkan terendah pada jarak $70 \mathrm{~cm}$ dengan jumlah 3 benih/lubang tanam (J3W3) yaitu, (218,52 gram). Hal ini menunjukan bahwa, kepadatan populasi sangat berpengaruh terhadap hasil buah jadi per rumpun dengan memperoleh cahaya, unsur hara dan air.

Menurut Suryana, (2003) salah satu faktor penentu produktivitas jagung adalah populasi tanaman yang terkait erat dengan jarak tanam dan mutu benih. Untuk memenuhi populasi tanaman tersebut, viabilitas benih dianjurkan lebih dari 95\% karena dalam budidaya tidak diperkenankan melakukan penyulaman tanaman yang tidak tumbuh karena peluangnya untuk tumbuh normal sangat kecil dan biasanya tongkol yang terbentuk tidak berisi biji.

Menurut Silaban, (2013) jarak tanam pada tanaman jagung berhubungan dengan ruang tumbuh yang ditempatinya dalam penyediaan unsur hara, air, dan cahaya. Jarak tanam yang terlalu lebar kurang efisien dalam pemanfatan lahan, bila terlalu sempit akan terjadi persaingan yang tinggi yang mengakibatkan produktifitas rendah. Pengaturan kepadatan populasi tanaman dan pengaturan jarak tanam pada tanaman budidaya dimaksudkan untuk menekan kompetisi antara tanaman. Setiap jenis tanaman mempunyai kepadatan populasi tanaman yang optimum untuk mendapatkan produksi yang maksimum. Apabila tingkat kesuburan tanah dan air tersedia cukup, maka kepadatan populasi tanaman yang optimumditentukan oleh kompetisi diatas tanah daripada didalam tanah atau sebaliknya.

Hasil penelitian Warisno, (2008) bahwa tanaman jagung akan dapat tumbuh dengan baik dan sempurna serta dapat dapat berproduksi tinggi bila mendapat sinar matahari yang cukup. Hasil jagung akan lebih tinggi bila ditanam di tempat terbuka dibandingkan ditanam di tempat yang ternaungi. Intensitas cahaya yang tinggi baik untuk pertumbuhan tanaman jagung. Intensitas cahaya yang rendah (di bawah naungan) akan berakibat tanaman jagung tumbuh memanjang, tongkol ringan, dan bijinya kurang berisi.

Dari hasil penelitian simamora (2007), perlakuan jarak tanam berpengaruh nyata terhadap hasil jagung perplot. Jarak tanam $60 \mathrm{~cm} \quad$ x $25 \mathrm{~cm} \quad(351286 \mathrm{~g})$ memberikan hasil lebih besar dibandingkan $75 \mathrm{~cm}$ x $25 \mathrm{~cm}(2853,33 \mathrm{~g})$ dan $90 \mathrm{~cm}$ x $25 \mathrm{~cm}(2474,67 \mathrm{~g})$, jarak tanam yang semakin renggang akan menyebabkan penurunan hasil sebesar $15 \%$ pada jarak tanam $75 \mathrm{~cm}$ x $25 \mathrm{~cm}$ dan $29 \%$ pada jarak tanam $90 \mathrm{~cm}$ x $25 \mathrm{~cm}$ besarnya produksi dipengaruh oleh jumlah populasi tanaman. Untuk meningkatkan hasil biji tanaman jagung salah satunya adalah dapat dilakukan dengan penambahan tingkat kerapatan tanaman per satuan luas. Jarak tanam yang lebih renggang menghasilkan hasil yang lebih besar per tanaman, namun pada jarak tanam yang lebih sempit sampai batas tertentu akan menghasilkan hasil yang 

lebih besar. Perlakuan $60 \mathrm{~cm}$ x 25 $\mathrm{cm}$ belum menimbulkan persaingan yang nyata antara tanaman jagung sehingga hasilnya lebih besar dibandingkan perlakuan jarak tanam $75 \mathrm{~cm}$ x $25 \mathrm{~cm}$ dan $90 \mathrm{~cm} \times 25 \mathrm{~cm}$.

Williams, (2011) pengaturan jarak tanam sangat berpengaruh terhadap pertumbuhan dan hasil tanaman. Hal ini akan berpengaruh pada luas daun, berat kering tanaman, sistem perakaran, banyaknya sinar matahari yang diterima, dan banyaknya unsur hara yang diserap dari dalam tanah. Penggunaan jarak tanam yang tepat akan menaikkan hasil, tetapi penggunaan jarak tanam yang kurang tepat akan menurunkan hasil

Sedangkan menurut Rohrig, (2009) besarnya persentase tongkol tidak berbiji berkorelasi positif dengan naiknya tingkat kepadatan tanaman dan hal ini merupakan faktor pembatas hasil jagung. Serapan cahaya matahari oleh tajuk tanaman merupakan faktor penting yang menentukan fotosintesis untuk menghasilkan asimilat bagi pembentukan hasil akhir berupa biji. Cahaya matahari yang diserap tajuk tanaman proporsional dengan total luas lahan yang dinaungi oleh tajuk tanaman.

\section{SIMPULAN}

Berdasarkan penelitian yang telah dilakukan dapat diambil kesimpulan sebagai berikut:

1) Perlakuan jarak tanam tidak memberi pengaruh terhadap pertumbuhan dan produksi jagung. Perlakuan tertinggi pada tinggi tanaman jagung 20 hst berada pada jarak tanam $50 \mathrm{~cm}$ dengan jumlah 2 benih/lubang tanam J1W2 yaitu, $(34,74 \mathrm{~cm})$ dan terendah pada jarak tanam $50 \mathrm{~cm}$ dengan jumlah 1 benih/lubang tanam J1W1 yaitu, $(28,56 \mathrm{~cm})$. Sedangkan perlakuan tertinggi pada tanaman jagung 40 hst berada pada jarak 60 $\mathrm{cm}$ dengan jumlah 2 benih/lubang tanam J2W2 yaitu, (113,00 cm) dan terendah pada jarak $50 \mathrm{~cm}$ dengan jumlah 1 benih/lubang tanam J1W1 yaitu, $(83,78 \mathrm{~cm})$.

2) Perlakuan jumlah benih tidak memberi pengaruh terhadap jumlah daun. Perlakuan tertinggi jumlah daun 20 hst berada pada jarak tanam $60 \mathrm{~cm}$ dengan jumlah 2 benih/lubang tanam J2W2 yaitu, (5,44 helai) dan terendah pada jarak tanam $50 \mathrm{~cm}$ dengan jumlah 1 benih/lubang tanam J1W1 yaitu, $(4,44$ helai). Sedangkan perlakuan tertinggi jumlah daun 40 hst berada pada jarak $70 \mathrm{~cm}$ dengan jumlah 1 benih/lubang tanam J3W1 yaitu, (10,78 helai) dan terendah pada jarak $50 \mathrm{~cm}$ dengan jumlah 3 benih/lubang tanam J1W3 yaitu, (8,20 helai).

3) Perlakuan kombinasi jumlah benih dan jarak tanam tidak memberi pengaruh terhadap bobot basah buah jadi . Perlakuan tertinggi pada bobot basah buah 80 hst berada pada jarak tanam $50 \mathrm{~cm}$ dengan jumlah 2 benih/lubang tanam J1W2 yaitu, (505,56 gram) dan terendah pada jarak tanam $70 \mathrm{~cm}$ dengan jumlah 3 benih/lubang tanam J3W3 yaitu,(218,52 gram).

\section{UCAPAN TERIMA KASIH}

Penulis mengucapkan terimakasih kepada semua pihak yang telah membantu sehingga penelitian ini dapat berjalan dengan baik. 
DAFTAR PUSTAKA

Arwani,\& Supriyanto,(2013). Penelitian Metodologi Kepemimpinan. Salemba Medika: Jakarta

Aribawa, I.B., Mastra, S., I.K, Kariada, 2007 Uji Adaptasi Beberapa Varietas Jagung di Lahan Sawah.Balai Penelitian Teknologi Penelitian Bali Nusa Tenggara Barat.Hal:1-3.

Arwadi, 2013. Tanaman Jagung. Proses Fotosintesi. Budidaya Pertanian. Bogor.

Berkelaar,D,. 2011. Sistem intesifikasi padi.(The sistem of rise intensificasion-SRI): Sedikit dapat memberi lebih banyak.Buletin ECHO DevelopmentNotes,Januari 2001, Issue 70, Halaman16.Terjemahan bebas oleh Indro Surono, staf ELSPPAT,Bogor,Indonesia.

Belfield, Stephanie \& Brown, Christine.2008. Field Crop Manual:(A Guide to Uplan Production in Cambodia). Canberra.

Bilman, 2011. Analisis Pertumbuhan Tanaman Jagung(zea mays L.) Pergeseran Komposisi Gulma pada Beberapa Jarak Tanam.

Cahyono,B.,2003. Kacang Buncis Teknik Budidaya dan Analisis Usaha Tani. Kanisius. Yogyakarta . Hal: 42.

Darliana, Setiawan. 2009. Atlas Tumbuhan Obat Jilid 6. Jakarta: PT Pustaka

Bunda.

Derna, H. 2007. Jagung Manis. Diakses di http://www.scribd.com/doc/3815872 3/jagung manis-no4.pdf.

Ermanita., Yusnida B dan Firdaus L. N., 2004. Pertumbuhan vegetatif dua varietas jagung pada tanah gambut yang diberi limbah pulp \& paper. Jurnal Biogenesis Vol. 1. Program Studi Pendidikan Biologi FKIP Universitas Riau. Pekanbaru.

Handoko, A., 2000. Budidaya Padi Secara Organik. Penebar Swadaya. Jakarta.
Harjadi,M.S.,2005.

Agronomi.Gramedia

Pengantar

Utama.Jakarata.

Harjadi.S.S.,2012.

Pustaka

Pengantar

Agronomi.Jakarta:

Gramedia.197.hal.

Harizamrry.2007. Artikel Jagung Manis.Diakses di http://harizamrry.com/2002/.../Tana man Jgung Manis-Sweet-Cron.

Harjadi, S. S. 2012. Pengantar agronomi. PT. Gramedia. Jakarta.

Haryanto B, Suhartini T, Rahayu E, dan Sunarjo. 2006. Sawi dan Selada. Penebar Swadaya. Jakarta

Hardjowigeno, S. 2005. Ilmu Tanah. Akademika Presindo, Jakarta.

Janick.J.2009, Hortikultura Sicience. San Francisco: W.H.Freeman Company.

Kurniawan, A. 2005. Pengaruh Tanah Lempung dan Blotong yang Diperkaya dan Digranulasikan terhadap Sifat Fisika dan Kimia Tanah serta Pertumbuhan Tebu pada Psammment Kabupaten Purworejo.Fakultas Pertanian. Universitas Gajah Mada. Skripsi.

Mattjik,A.A. dan I.M.Sumertajaya. 2006. Perancangan Percobaan Dengan Aplikasi. $\quad$ SAS dan Minitab.IPB. Press. Bogor. 276. Hlm.

Purwono,R,dan Hartono.,2004.Produksi jagung unggul. bayumedia publishing. Malang.

Purnomo dan Hartono.,2005.Bertanam Jagung Unggul.Penebar Swadaya. Jakarta.79 Hal.

Purwono.Hartono.2005

Bertanam Jagung Unggul.Jakarta. Penebar.Swadaya.

Rifin. Sujana, A.,A. Dan M. Sujadi. Jagung. Buletin Teknik No 3. Badan Penelitian dan Pengembangan Pertanian Balai Penelitian Tanaman Pangan Bogor. Jl. Tentara Pelajar 3 A bogor.

Rahmat Rukmana. 2005. Ganyon Budidaya dan Pascapanen. Yogyakarta. 
Rudi Hartono. 2005. Budidaya Tanaman Jagung Manis. Jakarta, Penerbar Swadaya.

Rukmana,Rahmat.2010.Jagung Budidaya Pascapanen,penganekaragaman pangan.Semarang. CV Aneka Ilmu

Rukmana. 2007. Budidaya Kacang Tanah. Kanisius. Yogyakarta.98.hal.

Mayadewi, Ari.2007. Pengaruh jenis pupuk pada Jarak tanam terhadap PertumbuhanTanaman Jagung.

Marzuki. R. 2005 . Bertanam Kacang Tanah.Penebar Swadaya.43. hal.

Mayadewi, N.N. 2007. Pengaruh Jenis Pupuk Kandang, dan Jarak tanam Terhadap Hasil Jagung Manis.Jurnal. Agritrop.26 (4): 153159.

Reta. Sanchez., D. G. And J. L., Fowler. 2002. Canopy Light Environment and Yielrd or Narrow-row Cotton as Affected By Canopy Architecture. Agron J. 94:1317-1323.

Rohring, M., H. Sutzel and C. Alt. 2009. A three-Dhimensional Approacht to Modelling Light Interception in Heterrogenous Canpies. Argon $J$. 91:1024-1032.

Safizal, R. 2010. Laporan Pratikum Satuan Oprasional.Kadar Air Bahan.Laboratorium Teknik Pasca Panen.Jurusan Teknik Pertanian.Fakultas

Pertanian.Universitas Syiahkuala.

Setiawan, A. N.2003. Teknologi Budidaya Pertanian Lahan Pantai dan Permasalahannya. Agr UMY 4 (2): 42-45.

Silaban,E.,T.e,Purba, J, Ginting.2013. Pertumbuhan dan produksi jagung manis (zea mays sacaratha strut L.), Pada berbagai jarak tanam dan waktu olah tanah.Agroteknologi, 1 (3):808818.

Simatupang.1997. Sifat dan Ciri- Ciri Tanah. IPB.Bogor.

Simatupang, R.S. 2006. Pengembangan Eks-PLG Teknologi Olah Tanah
Konservasi.Balai Penelitian Lahan Rawa. Hal:1-3.

Simamora,T.J.L. 2006. Pengaruh Waktu Penyiangan dan Jarak Tanam terhadap Pertumbuhan dan Produksi Tanaman Jagung (Zea maysL.) Varietas DK3. Skripsi.USU.Medan

Subandi dan Zubachtiron, 2005. Teknologi Budidaya Jagung Berdaya Saing Global. Makalah Disampaikan Pada Pertemuan Pengembangan Koordinasi Agribisnis Jagung. 1-2 Agustus 2005, di Bogor.

Suprapto dan Marzuki, 2005 Respon Pertumbuhan dan Produksi Tanaman Jagung ( zea mays Saccharata Strut).

Suryana,Achmad. 2003. Kebijakan Ketahanan Pangan Nasional (Online),(http://pse.litbang.deptan.go .id/ind/pdffiles/Anjak 2005 IV 15. Pdf).

Syafruddin dan Saidah, 2006. Produktifitas jagung dengan Pengaturan Jarak Tanam dan Penjarangan Tanaman pada Lahan Kering Lembah Palu, Penelitian Pertanian Tanaman Pangan.25(2):129-134.

Subandi, 2008. Varietas Bersari Bebas vs Varietas Hibrida pada Jagung. Hal: $1-5$.

Sumarno, W.B. 2008. Perakitan Varietas Jagung Hibrida.http://willy.situshijau.co.id. Hal: 1-9.

Warisno, 2003.Budidaya jagung hibrida.Penerbit

Kanisius.Yogyakarta. 2008. Jagung Hibrida. Yogyakarta. Kanisius.

Wiliam, C.N.,dan Jhosep, K . T., 1997. Climate Soil and Crop Production in the Humid Tropics.Oxford University. London

Wiliams,M.,R.A.Boydston,R.Ed.Peachey,a nd D.Robinson.2011.Signifiance of Atrazine as a Tank-Mix Partner with 

AGRICA, VOL. 11 NO. 2 (2018)

Tembotrione.Weed Management.25:299302.

Warisno,1998. Budidaya dan Produksi Jagung di Indonesia. Badan Ketahanan Pangan

Departemen, Pertanian, Jakarta.

Warisno, 2009. Jagung Hibrida. Kanisius, Yogyakarta.

Winarso,2005. Pupuk dan Pemupukan. Rineka Cipta.Jakarta. 